\title{
VIDEO CLIP AND ARTISTE'S IMAGE AS TOOLS OF THE SONG HIT'S MEDIAVIRUS ACTION STRENGTHENING (BASED ON THE UKRAINIAN AND RUSSIAN COMPOSITIONS OF LATE 20th - EARLY 21st CENTURIES)
}

\author{
Ivanna Shnur
}

PhD in Arts, Lecturer at the Music Department; ORCID: 0000-0002-8633-5244; e-mail: iv.phenix@gmail.com Municipal Institution of Higher Education "Kyiv Academy of Arts", Kyiv Academy of Arts, Kyiv, Ukraine

\begin{abstract}
An important place in mass music culture belongs to the song hit - a phenomenon which attributes have not still been explored well finally. Among them - a video clip as a specific form of hit's incarnation and an artiste's image as a communicative feature of the phenomenon's existence. The ascertainment of these aspects is the main objective of the study. The logic of achieving this objective led to the choice such a methodology: the method of analyzing scientific literature on the problem (to determine the degree of its elaboration and the prospect of further exploration), the method of intonation analysis (in the study of the musical language's features and the principles of composition's organization), the functional method (aimed at studying the degree of subject's dependence on audience's socio-cultural inquiries), the communicative method (that allows take into consideration the factor of the compositions' existence in the public consciousness, the audience's reaction to them and artiste's personality), the comparative method (to study the genre and intonation and also the individual image components of the song hit).

The song hit aims to reach the widest possible audience so this fact dues to the presence of such components as a media virus and a meme in its structure. They are directed at appealing to psychological "sensitive points", the rooting in the mind and the causing of their further distribution, they can be found at all the song hit's levels and they aim at the comprehensive coverage of the listener/viewer.
\end{abstract}

Results. The song hit's communicative nature determines the significance of its visual component represented by the video clip. In addition to the representative function, this embodiment is the most effective media virus tool.

Moreover, the hit's promoting, the marketing nature extends to its performer's competitiveness. This aspect involves the obligatory presence the viral properties in the image, which can cause the audience's emotional response. The artiste's representative function necessitates constant and purposeful work on his image.

Keywords: the song hit; the video clip; the meme; the media virus; the artiste's image; the pop music. 


\section{Introduction}

The study of the song hitphenomenon has paramount importance for understanding the specifics of the mass music and the modern music culture in general. We interpret the song hit as a socio-cultural musical product that is represented by a pop song mostly in love-lyrical content which has gained such quality as the recognition of a large audience because of memorization's easiness, reliance on the genreintonation vocabulary of the epoch, focusing on emotional response, the presence of an extraordinary performance image and the balance ratio of standardized and unique musical material.

Modern song hit potentially contains not only the audial component: it often includes a visibility and so it forms a synthetic product based on a song. Thereby the understanding of its visualization aspect is equally important. According to D. Rushkoff's (1994) modern mass phenomena are characterized by the features of mediavirus - a sociocultural phenomenon/event of the present, which instantly spread in the media space, infects a huge number of vector and corrects their minds in line with the most beneficial to the creators of the virus.

Our study's historical framework (the late 20th - the early 21 th centuries) reflects the various stages of the viral component's adaptation in the song hit. In this process, the video clip as a visual form of the song's existence has become especially important (it is noteworthy that D. Rushkoff relies precisely on a video clip studying the pop songs' viral features).

The song hit communicative nature determines the involvement of the actual mass communication, implements also the using the most demanding and democratic forms of material's representation. Thus, the video clip immanently involves the visual communication channel that serves as the cornerstone in the acquisition of the composition's song hit status.

\section{Analysis of recent researches and publications}

There are various studying aspects of the video clip in Ukrainian and Russian video clips' researches among them the typology and the features of origin and development (Eliseeva, 1989; Samutina, 2001), the content component and the synthesizing nature of the video (Chernyshov, 2014), etc. However, in spite of that, the following questions are unconsidered: the correlation of the audial and visual components' in the song hit and also their interaction in the process of song's popularizing. T. Cherednichenko's comprehension of the song hit (1994) is not well argued and somewhat emotional (despite its scientific value). In particular the scientist clarify the clip's essence (Cherednichenko, 1994, p.182-185) and repeatedly emphasize the monotony and discreteness of its audiovisual up to underlining the inherent phenomenon of "time and space disintegration" (Cherednichenko, 1994, p.184). At the same time the video clip's essential feature was not highlighted - the interconnection of its audio and video components. As for the artiste image's papers, most of them are devoted to the certain performers (Razzakov, 2003) or the musical management's specify (Sukhanov, 2012; Strakovich, 2014) but no one of them contains the system analysis of particular 
artiste image's elements that promote the memorization of song interpretation. Therefore, these aspects need more details.

\section{Presentation of the main material}

In our opinion there are such specific components in the video clip that are absent in the song hit of its "pure", only audio existence: discrete and heterogeneous visual elements. The song hit (as a clip's audio component) has a cementing function: it consolidates the video fragments and forms a new, highly attractive mass culture product. In turn the connection of heterogeneous video elements amplifies the song hit's tendency to mix and to combine multi-level components within the composition (from verbal-intonation to individual-performing). This leads to the obligatory dialogicity of the audio and video constituents which is indicated by the researchers: N. Samutina (2001) accents the indisputable unity of the video and the song in it. In our opinion these features not only enhance the attention to the clip but also give it additional hook ${ }^{1}$ properties. We argue this position through a comprehending of the indicated dialogicity in detection of its hook qualities.

One of the most prominent features of such a dialogue is the tempo-rhythmic, time correlation of visual and intonation aspects: in comparison with audio the video may be "accurate", "outrunning", "delayed" - it must relate with the song's rhythm (Samutina, 2001). The type of these components' tempo-rhythmic combination additionally enhances the emotional perception of song imagery. For example, in video "Taka yak ty" ("Such as you") by "Okean Elzy" audio's tender and hearty emotions are emphasized with "delayed" montage rhythm and the smooth, "sliding" motion of the camera.

The reason for the "delayed" video's infrequent application is the predominance of a typical clip montage that is characterized by speed, rhythm and acuteness (Samutina, 2001). The analysis of Ukrainian and Russian video clips of the 1990-2010th shows the dominance of an "outrunning" type of video rhythm which is emphasized by a sharp and rapid change of visual fragments. We think that this tendency is due to the video directors' desire to give the clip an additional dynamism, activity and impulsivity, among a huge number of examples: "Potselui" ("The Kisses") by "VIA Gra", "Furiya" ("The Fury") by "Druha Rika" and "Na raYOne" ("On the District") by Potap and Nastya Kamenskykh.

As researchers note (Eliseeva, 1989; Rushkoff, 1994; Sokoliuk, 2009), the video clip becomes the main form of the hit's existence because of the specialized channels' emergence that broadcast clips and playback tools (household video equipment and video cassettes). Thus the using of the latest technological phenomena in the song hit's dissemination, on the one hand, reflects the technogenic era's peculiarities and, on the other hand, it seeks to strengthen the song hit's hook attributes by including the visual component. Moreover, in a number of cases this component itself acquires the quality of the hook due to the presence in the clip a variety of special effects: the animations, the video effects, the computer graphics, etc. The visual component's

\footnotetext{
${ }^{1}$ We understand the hook as an intonation-contrast element, which promotes the audience activation and leads to update of the listener's feelings.
} 
enrichment with the latest technical practices is comparable to using a variety of audio effects (e.g., the echo, the changing of the playback speed, the playback in the reverse direction, etc.). In both cases the main goal is to attract the listener's attention.

Another feature of the video and audio components' community of the song hit is the movement dynamics, which enhances its hook signs. This quality is represented often by dance (a large number of song hits of all the times are based on the dance: for example, the Eurodance in the 1990's or R\&B in 2010's). Among other ways of its embodiment are the artiste's skill and the collage of "sliced" video fragments.

It is important a dance genre's popularization to be combined with the commercial nature of the video clip. This aspect represents a star-artist who makes moves with a music. It is no coincidence the artiste's presence on the screen. It is a required condition for a clip (Samutina, 2001). Similar to the song hit's commercial substance the clip's commerciality led to the crystallization of some clichés in it ${ }^{2}$, among them: the performers' clothes, their language and gesture, the video space's entourage, the shooting's type, the plot's type, etc. (Samutina, 2001). So just like using typical intonations in the song hit, there is a standardization of all the clip's levels: from the gestures and the language's specifics up to the general plot. But as in the case of audio-hit the operation of stable visual fragments does not necessarily indicate a low quality of a clip: on M. Eliseeva's (1989) mind "a well-constructed clip can be called an audiovisual sonnet - strict timeframes, functions and aesthetics made it a some special genre" (p.16).

In addition to the commercial essence the song hit's visualization accumulates the most effective viral-memetic components that encourage listeners to spread it. Among them are memes, which appeal to the genetic "sensitive points" and sociocommunicative instincts (according to R. Brodie, 1996): sensuality, anxiety, food, belonging to community, obedience to authority, etc. Consequently, we investigate the specificity of the video clip's viral-memetic nature as a synthetic product.

Like the song hit's intonation content the most demanded and used elements of the music video are connected with the sensuality and anxiety memes. A typical example of a based on a dance music video is "Okean i tri reki" ("The Ocean and Three Rivers") by V. Meladze and the band "VIA Gra". In addition to the intonation component, vigorous dance acquires a dominant role in the video and gives additional viral properties to the hit.

In this aspect, central importance has a specific interpretation of dance in the pop culture by T. Cherednichenko (1994). The scientist designates the following its connotations: "the environment of bodily energy", "the plastic capabilities' play", "the erotic symbolization" (p.161). Obviously, the result of such a rhythm-dance component's positioning is the sensuality meme's actualization. The "duties' division" of the clip's participants is interesting: the modern-dance group embodies "the environment of bodily energy" and "the flexible capabilities' play" (because of the graceful and simultaneously active-sharp choreography which is typical for the modern musical) while the soloists' plasticity is permanently aimed to broadcast of erotic sensuality.

\footnotetext{
${ }^{2}$ The clip's clichés significance is best illustrated by M. Eliseeva (1989): "often the clip is a set of clichés. But it should keep in mind that a gigantic work has been done to find these clichés so there is no reason to neglect this experience" (p.16).
} 
This clip's intonation and visual components' dialogicity way are the domination of sensuality and attention activation memes (attention activation meme is derived from the anxiety meme). Therefore, it is typical to use in "Ocean and Three Rivers" clip with a quick and sharp frames changing which contributes to the complementarity of the multi-level components. In the verse the composition's main "actors" are compared: V. Meladze (his melody contains the attention activation meme [risingiambic P4] and sensuality meme [rising m6 on distance]) and the group "VIA Gra" (the melody is based on the singing within the limits of 3 sounds). The chorus contains a sensuality meme in a veiled form: smooth-winding melodic deployment (it is the best suited to the reproduction of the rivers' whimsical flow, which is also referred with the verbal text) is carried out in the small-scale range $\left(f^{1}-a\right)$.

It is significant that in the clip "Ocean and Three Rivers" the embodiment of "the erotic symbolization" (according to T. Cherednichenko, 1994) contributes the attraction of various cultural phenomena which are on different sides of the "cultural abysm". On the one hand, it is a reminiscence of well-known canvases that are a kind of art hits with nudity ("Venus Anadyomene" by Sandro Botticelli, "Grande Odalisque" by Jean-Auguste-Dominique Ingres and "Danaë" by Rembrandt) and also are the masterpieces of undeniable artistic value. On the other hand there are the mise en scenes with a typical women's stylistic image for an erotic films (the pseudoshy behavior, the emphasized bright makeup, the seductive body's plastic). It is worth noting the using in this clip the erotic mise en scenes reflects the practice to saturate the visual range by sensual elements that was typically in the mid-1990s films and was indicated by researchers in the cinema art sociology ${ }^{3}$. The totality of the intonational, choreographic, pictorial and image components defined in this clip forms such a vivid video product that subsequent listening of the hit "Ocean and Three Rivers" causes visual "pictures"-memories. In addition, the viral-memetic components contribute to this composition's further solidification in the memory.

A special aspect of the viral-memetic nature's embodiment is the presence of a belonging to community meme in song hit. Such compositions reflect the demands of some socio-cultural groups - usually with a marginal status. Among them, there is one of the most popular in the post-Soviet mass culture: so-called Gopniks - young people whose mentality and lifestyle are in violation with generally accepted norms of behavior ${ }^{4}$. Although these videos' target is young people (due to the declaration of rebellious behavior), we believe that these clips' peculiarity leads to the appearance of a hook effect for a wide audience. It is significant that the clips' topics reflect the demands of "the margins" and led to the use the typical media virus mechanism for

\footnotetext{
${ }^{3}$ For example, K. Tarasov outlines the situation in 1994th: "Russia has apparently entered the forefront in the cinema world community with the volume of the erotic and pornographic mass that spills on the screen. The screenplay clearly aims to satisfy symbolically the audience's sexual needs" (Tarasov, 1994, p.64). This trend is typical also for Ukrainian cinema so in the video "Ocean and Three Rivers" the using of sensual images is natural and justified.

${ }^{4}$ Hopnik is "the representative of the subculture which was formed as a result of criminal aesthetics' infiltration in the working environment; a person who demands money or valuable things from other people, a crook, a robber, a hooligan. Hopniks are self-asserted by inflicting humiliation and injustice of other people. A typical gopnik can cling to passers-by for no reason if he feels they cannot stand for themselves' (Gavriliuk, 2010, p.126).
} 
the rooting of memes to the mind - the cognitive dissonance method. For example, the clip "Na raYOne" ("On the District", 2008) by Potap and Nastya Kamenskykh declares a frankly gopnik theme which representation is in all the structural video and audio components, among them:

- unpretentious melody with the predominance of intonation "trampling" on 2-3 sounds which is subordinated to the repeating harmonic sequence t-VI-s-D - it is the conscious involvement of musical language's specific elements that are easy to intonation by representatives of the target audience;

- visual conversational preamble and completion (performed by residents of the project "Comedy Club Ukraine" T. Batrodinov and A. Burim) which depict the typical image of this marginal subculture's representatives;

- using of such a video material is depicting an ordinary commuter town (nondescript Khrushchyovkas, a flea market, observant grandmothers on a bench, the carpet's knocking out, children's jumping on an elastic band, etc.);

- Potap and Nastya's performance in the "field" conditions - the artistes represent the Gopnik's image stylistics relief and in a somewhat romantic key: aggressiveswirling facial expressions and gestures, eccentric submission of verbal text (he is generously replete with slang expressions like "Vasya, chto ty gonish?" ["Vasya, what are you lying about?"] or "zayavu eyo batya nakatal togda nekstati" ["her dad drove the claim fortuitous then"]), tasteless pretentious style of clothing with the numerous gold adornments (mostly the massive chains).

Particular attention deserves the verbal-intonational component of this clip. According to YouTube-reviewer I. Oleignikov (Igor Chi1i) the intonational aspect of the hit "On the District" is an outright plagiarism of the composition "Applausi per Fibra" (2006) by Italian rapper Fabri Fibra: "That's really impossible to make a complete song list of this person [Potap $=0$. Potapenko - I. Shnur] and his team have stolen from other stars because they rush out all themselves are listening to. It's interesting that the greatest Potap and the company's hits were borrowed from other well-known tracks" (Oleinikov, 2013). Thus, the modification of the original composition took place exclusively within the hit's text-verbal component. It is significant that Potap's composition borrowed from Fabri Fibra's song all the audioconceptual material including the accompaniment's timbre-intonational component. We would not focus on the ethical aspect of this but note that despite the great degree of heredity the hit "On the District" transforms the emotional and semantic assertion due to the using of another plot. In "Applausi per Fibra" we see the narrative about the life's difficulties - the domination of depressive-brown color is largely contributing to this. Whilst the visual component of Potap's hit was made with a greater claim to chic, the apparent desire is to carol the gopnik's way of life: it is manifested with underlined-bright colors of "picture".

In spite of the fairly high artistic and technical quality of this group clips they are a kind of sympathy for the unpretentious taste of mass products' typical consumer. It is significant that these hits' visual representations reveal the the post-Soviet person's latent mental characteristics. Thus according to N. Kuznecova, although the times of the gopniks' widespread physical domination became part of the 1990's history yet their image's brightness would forever lay in the modern man's mind. 
"The vestige of the gopnik-gene is manifested in the fact that even the most quasiwestern-looking young Russian person carries a classic gopnik's outlook in his heart: the blind chauvinism, the anti-Americanism, the hatred to blacks and of course a tendency to gopnik's tricks on Aeroflot flights, when even the richest Russian can feel the influence of his hopnik's recessive genes" (Kuznetcova, 2007). Therefore, in the clip "On the District" there is a purposeful appealing to the subject that has a response in the Slavic mentality and has signs of deliberately created media virus.

The song hit's marketing essence leads to the extraordinary commercial potential not only the song itself but also its performer. In the 20th - early 21st centuries the industrial specifics of the hit's writing and distribution was increased by the significant technological development and the formation of the musical enterprise's phenomenon (recording companies). These structures led to the emergence of the hit and star artiste because "disproportionately large resources were invested in the promotion of a small part of musical products - potential bestsellers - that causes the dominance of the so-called system of hits and stars" (Strakovich, 2014, p.30-31). Consequently, the "win" compositions almost always are approved by the musical industry so it proves the thesis that the song does not become a hit without its powerful popularization even despite the well-made hooks.

It is important the musical corporations' financial support is too far from everyone who wants to sing. The marketing approach works in this aspect too because "no one label will work with a musician "from scratch", an experienced producer chooses an artiste who has the charisma, knows how to move on the stage and has enough concert experience" (Sukhanov, 2012, p.26). This rule's exceptions are the television vocal shows ("Voice of the Country", "Factory of Stars", "X-Factor", etc.) which specificity is precisely to show the production process of the "star" artiste from the average person (among the examples - the singers Alekseev, P. Gagarina, A. Matvienko, V. Romanchenko, Timati).

The fashion phenomenon has a significant effect on the artiste's image by adhering to specific fashion criteria: matching with actual audience demands and the presence of a certain artistic image. These positions define the most typical features of song hit's artiste:

- The free artistic manner as a means of communicating with the listener. In our opinion because of this, the sensuality meme is inherently characteristic of pop image with varying intensity of its appearance.

- Domination of image provocative as a way of keeping the attention and the main tool of the artiste's popularization ${ }^{5}$ - thus aggravating the composition's hook and viral essence.

- Specific emotions' expression as a reality's recreational simulacrum.

Thus the pop artiste's image must contain certain components that are able to "act" on the audience as much as possible: the memetic elements (mostly attracted by the sensuality meme), somewhat that keeps an attention (mainly due to the image's provocative nature) and the relevance that embodied in the entertainment key.

\footnotetext{
${ }^{5}$ According to V. Sukhanov, "the provocation became a kind of mass demand. A significant role in this was played by advertising that made a provocation into a cult" (Sukhanov, 2012, p.25).
} 
It should say the image has a multi-level structure: it includes the artiste's appearance, his suit, stage behavior and the peculiarities of individual performance. However, no less importance has such an essential characteristic as the timbre and intonation vividness of the voice, which ensures the artiste's recognizability. At the same time, the performer's specificity (the regional accent, the diction "defects", etc.) should be an artiste's charm, and not an obstacle in the listener's perception. An example of such the "incomplete" charm is the slight hoarseness and some burry that immanent to the manner of S. Vakarchuk.

As we see, the individual artiste's image has a paramount importance to the song hit and it necessitates the study of the Ukrainian-Russian pop performers' image specificity. So let us comprehend the most significant images of the 20th - early 21 st century's performers.

The Soviet artiste's image reflected the ideological inquiries so there is no provocative in it. Depravity and frivolity were identified with bourgeois pop art whereas Soviet artists emphasized love for the Motherland (for example, I. Dunayevsky's "March of enthusiasts" performed by L. Orlova, Dm. \& Dan. Pokrass' "Moscow May" in the performance of V. Bunchikov and V. Nechaev).

The Soviet artiste's image envisaged extreme modesty of the clothes: a strict suit and a shirt with a tie in men, modest dresses for women and also unpretentious scenic behavior. It should be noted that in addition to observing the ideological guides the artiste's "stiffness" is due to the technical peculiarities of that time: the microphones should be hold in the same position because of the background effect's significant probability so the artistes were not able to move with them. But even this "inconvenience" contributed to the inner emotions' concentration and emphasized the artiste's sculptural expressiveness even a certain bulkiness of the image, especially for male artistes (for example, the concentrated and at the same time inspired performance of the song "My Moscow" by M. Bernes).

The Soviet image was a kind of the genre-intonation concept's continuation: either sincere lyricism that prompts listening to songs as an old friend's stories, or concentrated concert songs based on the march genre, which emphasizes the performer's social status as a "speaker of ideas" and an ideologue.

At the end of the Soviet period (1970-80's) was formed another image style, it was aimed to the competitiveness with Western songs that penetrated from the "Iron Curtain". One of the brightest is the image of A. Pugacheva whose originality is based on the so-called "theater of songs" - the underlined theatricalization of the performance. In this artiste's representation a song appears to be a solo performance and a kind of musical theater. For example, during the performance of the song "Arlekino" (1975) A. Pugacheva involved the principle of concentrated influence on the listener: "the expressive effect is achieved not only by intonation but also with the appearance. Before culminating, with a few movements the artiste creates a hairstyle that shades her as much as possible. On the words of the culmination "I will take a mask and this world will change with me" the singer removes hair from her forehead pronouncedly in the slow movement" (Razzakov, 2003, p.104). Significantly, A. Pugacheva's emphasis on the spectacular performance is a consciously formed image 
strategy ${ }^{6}$, which the artiste adheres to throughout the creative path ${ }^{7}$. Moreover the well-developed strategy of "theatricality" went beyond the purely performing image and led to creation of the production center "Theater of the Song" (since 1988) which is engaged in organizing the cultural events (the festival "Christmas meetings"), the tours, the albums and souvenirs releases, as well as production activities.

After the USSR's collapse, the post-Soviet artiste's images arose "offhand" in accordance with the rapid pace of the formation of a broad-based pop industry. Their main property was the imitating the external features of Western pop music: the sensual liberty, the dynamism and the comprehensive dance. Borrowings concerned both visual and genre-intonational components: instantly the dominant genre style became Eurodance that was popular in the world wide practice (the stability of artificialsynthesizing sound, the obligatory presence of a synthetic inflammatory bit as if it was whiped up), for examples, "Ruchki" ("Arms") by the group "ViRUS!" and "Chao, bambina" by the group "Kar-Men".

In the subsequent $\left(2000-2010^{\text {th }}\right)$, the post-Soviet musical industry is characterized by a general "strategy of minimizing costs" (Frolov, 2007, p.70) and it has a predominance of images' imitation. There are practically absent specific indicators can distinguish the singers' image. The majority of Ukrainian and Russian pop artists' images are presented as some kind of the following signs' compilation: the declaring a "glossy" image, the accentuating the external data, the presence of sensuality elements. Meanwhile the lack of their originality and the absence of creative approach to the image largely deprives the pop artists of the individual. Their images are diversified exceptionally by stage costumes: for example, Dima Bilan's street style (the jeans, the shirt, the sneakers), F. Kirkorov's and M. Baskov's glitteringly-overflowing clothes or Ani Lorak's and S. Loboda's pompously-shining and, at the same time, sexually-relaxed stage clothes.

In our opinion, image's secondary is one of the reasons for the post-Soviet pop music's absence on the international level. In those cases when the efforts to create an original performing image were made the pop artist gains worldwide recognizability. For example, an image-makers team developed image of the singer Ruslana (R. Lyzhychko) filled with "wild" energy that played one of the key roles in her victory at the Eurovision Song Contest 2004 and greatly increased the recognizability of this artiste on the international arena.

\footnotetext{
${ }^{6}$ F. Razzakov's cites a dialog between A. Pugacheva and A. Stefanovich (a film director and her future husband) who prompted her to interpret this image: "you are a wonderful artiste, this is your strongest side, develop it. Strive to play all your songs, turn it into a theater". Pugacheva was extremely interested in this proposal. She asked, "how can I do that?". "Well, make a little play from the song. You should have such a dress, which can be transformed into various stage suits so that you can play several different roles. In general you have to handle any requisite". "But there is only a microphone in my hands". "Right. But who prevents you from making it, for example, a scepter or a glass?" (Razzakov, 2003, p.40).

7 To prove this thesis let us give an impression of $\mathrm{A}$. Pugacheva's performance in the newspaper "Na smenu!" ("On shift!", 1965): "Today Alla Pugacheva makes a solo performance on the stage, it is a theater of one actor. Yes, it is the theater because Pugacheva not only sings well but also she creates a song's visible image - a capacious, an expressive. Everything "works" for the song: the magic of the hands and the magic of the eyes, the luxury of obedient hair, the tactfully confused, the smooth, suddenly thrown back from the forehead and revealing the clear face of the Madonna, and the progressive, mournful and elegant, clumsy and volatile dress (Alla calls it in a theatrical way - a suit and even a boilersuit) which becomes a little girldress and even the clown's cloth for her whim" (Quoted by Razzakov, 2003, p.73).
} 


\section{Conclusions}

There is the variety of ways in representing the song hit's visual aspect. The using of the latest technical effects and vivid cultural phenomena suggests that the clip continuously absorbs and comprehends all the appearances that can hook the viewer's attention and firmly root in memory. The visual contexture's saturation with powerful memes and memo complexes has the extremely important role in this process. This aspect emphasizes the importance of media virus as a video clip's essential feature. Moreover, the virus components' involvement to the video is conscious and purposeful: there is no coincidence that in D. Rushkoff's typology the video clips refer to the intentionally created media viruses (Rushkoff, 1994, p.218).

As for the clips' quality, in our opinion, the numerous factors of the video's diversification cause precisely the monotony's avoidance mentioned by T. Cherednichenko (1994, p.184). On this occasion, there is an existence of a large number of resources in the Internet that are dedicated to the video clip's montage and contain numerous recommendations of avoidance the visual routineness. For example, one of them recommends to alternate smooth changes of the frame with fast transitions and to contain the most beautiful footages on the strongest music accents (Khaprichkov, 2016). As we see, the visual products' creators are deliberately aimed at maximizing the audience's attention by diversifying the tempo and rhythmically emphasizing the video's brightest moments.

It is important that such a strong concentration on the video is due to its specificity status in the structure of mass culture on the borders 20th-21th centuries. In this regard, the relevance has Y. Strakovich's thesis about the change of the video clip's role: "in the 20th century music video was a kind of advertising that leads to the musical product's purchase; in the 21 st century the clip is a final product created to keep the audience's attention" (Strakovich, 2014, p.287). As we see the change of the video clip's structure and functions has caused the modification of the song hit's compositional specificity: in the XXIst century the visual component acquires the most importance in hit's structure and provides a new, extremely wide field for the hook qualities' implementation. In the music video itself the emphasis shifts from the representative function (associated with the hit's visual embodiment, the artiste's presentation and the image declared by him) to the communicative: the clip becomes a kind of "message" translator from the performer to the listener/viewer and, in addition, from one viewer to another which underlines the D. Rushkoff's opinion about the video clip as the most effective media virus tool (Rushkoff, 1994, p.211).

It should be noted that in the hit's structure the artiste's image plays one of the leading roles since the song's performer acts as its representative, he is a key figure in the perception process. The actual tendency of saturation with the hook and viral elements all the constituents causes the exceptional role of the artiste's image: under the condition of continuous and professional work with it there is the great potential for song popularizing and imparting it the hit qualities. 


\section{References}

Arbatskaia, E. (2018). Biologicheskie metafory $v$ teorii mediaa [Biological metaphors in media theory]. Verhnevolzhskij filologicheskij vestnik, 4, (15), 45-50. doi:10.24411/2499-96792018-10195 [in Russian].

Brodie, R. (1996). Virus of the Mind: The New Science of the Meme. Seattle-Washington: Integral Press [in English].

Cherednichenko, T.V. (1994). Muzyka $v$ istorii kultury [Music in the history of culture] (Vol. 1). Dolgoprudnyj: Allegro-Press [in Russian].

Chernyshov, A. (2014). Sekrety pesennogo video [The secrets of the song video] Mediamuzyka, 3. Retrieved from http://mediamusic-journal.com/Issues/3_3.html [in Russian].

Eliseeva, M. (1989). Klipy i vshlipy [Clips and sobs]. Smena, № 17, 16-17 [in Russian].

Frolov, D. (2007). "Popsa": uproshhenie institucii iskusstva ["Pops": the simplification of the institution of art]. Ekonomicheskaia sotciologiia, 8, 4, 60-72 [in Russian].

Gavriliuk, V. (2010). Gopniki kak fenomen v srede molodezhi [Gopnik as a phenomenon among young people]. Sotciologicheskie issledovaniia, 1, 126-131 [in Russian].

Khaprichkov, I. (2016). Operativnyi montazh klipa. Kliuchevye momenty. Videourok [Quick installation of the clip. Key points. Video tutorial]. Pervaia virtualnaia vystavka fotoindustrii. Retrieved from https://photowebexpo.ru/expo/photo_school/lessons/ operational-mounting-clip-key-points-lesson [in Russian].

Kuznetcova, N. (2007). Kuda ty delsia, russkii gopnik? [Where are you, Russian Gopnik?]. Komsomolskaia pravda. Retrieved from https://www.crimea.kp.ru/daily/23915.4/68429/ [in Russian].

Oleinikov, I. (2013). "Plagiat" shou ["Plagiarism" show]. CarambaMusicShow, epizod 4: "Rusish plagiatish". Retrieved from https://www.youtube.com/watch?v=inzxDkEn2x0 [in Russian].

Razzakov, F. (2003). Alla Pugacheva: Po stupeniam slavy [Alla Pugacheva. The steps of glory]. Moscow: lauza [in Russian].

Rushkoff, D. (1994). Media Virus! Hidden Agendas in Popular Culture. New York: Ballantine books [in English].

Samutina, N. (2001) Muzykalnyi videoklip: poeziia segodnia [Music video: poetry today]. Neprikosnovennyi zapas, 6, (20) [in Russian].

Sapanzha, O., \& Ershova, D. (2017). Art-mem v diskuse sovremennoi kultury : analiticheskie statusy i prakticheskie vozmozhnosti [Art-meme in the discussion of modern culture : analytical statuses and practical opportunities]. Mezhdunarodnyi nauchno-issledovatelskii zhurnal, 12(66), 2, 34-37. doi:10.23670/IRJ.2017.66.038 [in Russian].

Sokoliuk, S. (2009). Obrazna struktura videoklipu: evoliutsiia rozvytku [Image structure of the video clip : the evolution of development]. Mystetstvoznavchi zapysky, 16, 132-140. [in Ukrainian].

Strakovich, lu. (2014). Tcifroliutciia. Chto sluchilos s muzykoi v XXI veke [Digitizing. What happened to the music in the XXth century]. Moscow: Klassika-XXI [in Russian].

Sukhanov, V. (2012). Fenomen muzykalnykh leiblov v sovremennoi Rossii [The phenomenon of music labels in modern Russia]. Vestnik Sankt-Peterburgskogo gosudarstvennogo instituta kultury, 2, 25-28 [in Russian].

Tarasov K. (1994). Eroticheskoe kino: pro \& contra [Erotic movie: pro \& contra]. Sotciologicheskie issledovaniia, 4, 64-69 [in Russian]. 
Zhurkova, D. (2019). Slozhnaia sudba "prostykh" form: otechestvennaia traditciia izucheniia populiarnoi muzyki [Difficult fate of "simple" forms: the domestic tradition of studying popular music]. Muzykalnaia kultura, 1, 192-213. doi:10.24411/2226-0072-2019-00009 [in Russian].

\section{ВІДЕОКЛІП ТА ВИКОНАВСЬКИЙ ІМІДЖ ЯК МЕХАНІЗМИ ПОСИЛЕННЯ МЕДІАВІРУСНОЇ ДІЇ ПІСЕННОГО ШЛЯГЕРУ (НА МАТЕРІАЛІ УКРАЇНСЬКИХ ТА РОСІЙСЬКИХ КОМПОЗИЦІЙ КІНЦЯ XX - ПОЧАТКУ XXI СТОЛІТТЯ)}

\section{Іванна Шнур}

кандидат мистецтвознавства; ORCID: 0000-0002-8633-5244; e-mail: iv.phenix@gmail.com

МЗВО «Київська Академія мистецтв», Київ, Україна

\section{Анотація}

Чільне місце в масовій музичній культурі належить пісенному шлягеру - явищу, деякі особливості якого досі не мають ґрунтовного осмислення. Серед них - відеокліп як специфічна форма втілення шлягеру та виконавський імідж як комунікативний засіб побутування даного феномена. 3'ясування цих аспектів становить мету дослідження. Логіка досягнення зазначеної мети зумовила вибір методів дослідження: метод аналізу наукової літератури з проблеми (для виявлення ступеня її розробленості та перспективи подальших розвідок), метод інтонаційного аналізу (при дослідженні особливостей музичної мови, принципів організації цілого), функційний метод (спрямований на вивчення міри залежності предмету дослідження від соціокультурних слухацьких запитів), комунікативний метод (дозволяє враховувати чинник побутування композицій у суспільній свідомості, реакцію аудиторії на них та особистість виконавця), компаративний (для вивчення жанрово-інтонаційної та індивідуально-виконавської складових пісенного шлягеру).

Націленість пісенного шлягеру на охоплення щонайширшої аудиторії зумовлює наявність у його структурі таких складових як медіавірус та мем. Вони спрямовані на апеляцію до психологічних «чутливих точок», укорінення в розумі й своє подальше поширення, вони можуть міститися на всіх рівнях пісенного шлягеру та мають за мету всебічне охоплення слухача/глядача.

Висновки. Комунікативна сутність пісенного шлягеру зумовлює значущість його візуальної компоненти, представленої відеокліпом. Таке втілення пісенного шлягеру, окрім виконання репрезентативної функції, $є$ найдієвішим медіавірусним інструментом.

Окрім засобів популяризації композиції, маркетингова природа шлягеру поширюється й на конкурентоспроможність її виконавця. Цей аспект передбачає обов'язкову наявність в іміджу артиста вірусних властивостей, здатних спричинити емоційний відгук аудиторії. Репрезентативна функція виконавця пісенного шлягеру зумовлює необхідність постійної та цілеспрямованої роботи над іміджем.

Ключові слова: пісенний шлягер; відеокліп; мем; медіавірус; виконавський імідж; попмузика 


\section{ВИДЕОКЛИП И ИСПОЛНИТЕЛЬСКИЙ ИМИДЖ КАК МЕХАНИЗМЫ УСИЛЕНИЯ МЕДИАВИРУСНОГО ДЕЙСТВИЯ ПЕСЕННОГО ШЛЯГЕРА (НА МАТЕРИАЛЕ УКРАИНСКИХ И РОССИЙСКИХ КОМПОЗИЦИЙ КОНЦА ХХ - НАЧАЛА ХХІ ВЕКА)}

\section{Иванна Шнур}

кандидат искусствоведения; ORCID: 0000-0002-8633-5244; e-mail: iv.phenix@gmail.com МУВО «Киевская Академия искусств», Киев, Украина

\section{Аннотация}

Главное место в массовой музыкальной культуре принадлежит песенному шлягеру явлению, некоторые особенности которого до сихпор не имеют основательного осмысления. Среди них - видеоклип как специфическая форма воплощения шлягера и исполнительный имидж как коммуникативное средство бытования данного феномена. Изучение этих аспектов составляет цель исследования. Логика достижения названной цели обусловила выбор методов исследования: метод анализа научной литературы по проблеме (для выявления степени её разработанности и перспектив дальнейших исследований), метод интонационного анализа (при исследовании особенностей музыкального языка, принципов организации целого), функциональный метод (направлен на изучение степени зависимости предмета исследования от социокультурных слушательских запросов), коммуникативный метод (позволяет учитывать фактор бытования композиций в общественном сознании, реакцию аудитории на них и личность исполнителя), компаративный (для изучения жанрово-интонационной и индивидуально-исполнительской составляющих песенного шлягера).

Нацеленность песенного шлягера на охват самой широкой аудитории обусловливает наличие в его структуре таких составляющих как медиавирус и мем. Они направлены на апелляцию к психологически «чувствительным точкам», укоренение в разуме и свое дальнейшее распространение, они могут содержаться на всех уровнях песенного шлягера и имеют целью всесторонний охват слушателя/зрителя.

Выводы. Коммуникативная сущность песенного шлягера предопределяет значимость его визуального компонента, представленного видеоклипом. Такое воплощение песенного шлягера, кроме выполнения репрезентативной функции, является самым действенным медиавирусним инструментом.

Кроме средств популяризации композиции, маркетинговая природа шлягера распространяется и на конкурентоспособность её исполнителя. Этот аспект предполагает обязательное наличие в имидже артиста вирусных свойств, способных вызвать эмоциональный отклик аудитории. Репрезентативная функция исполнителя песенного шлягера вызывает необходимость постоянной и целенаправленной работы над имиджем.

Ключевые слова: песенный шлягер; видеоклип; мем; медиавирус; исполнительский имидж; поп-музыка 